\title{
Public spending on rural tourism in Sweden
}

\author{
ÅSA ALMSTEDT, LINDA LUNDMARK AND ÖRJAN PETTERSSON
}

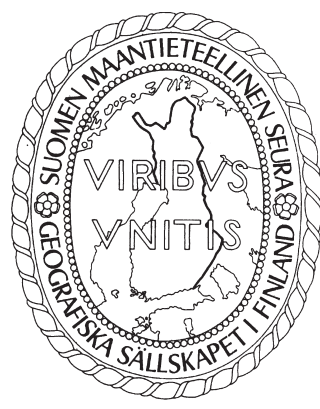

Almstedt, Åsa, Linda Lundmark \& Örjan Pettersson (2016). Public spending on rural tourism in Sweden. Fennia 194: 1, 18-31. ISSN 1798-5617.

\begin{abstract}
Tourism is an important part of rural policies in European countries. An increased demand for rural amenities is seen as creating a more diversified labour market and contributing to the restructuring of the economy, from primary sectors and manufacturing to a more service-oriented economy, which has been termed a "new rural economy". As a result, and as often presented in many policy documents, tourism is now seen as a universal tool for rural development. The purpose of this study is to investigate the distribution of public spending on tourism in rural areas in Sweden. It focuses on public spending on the main programme for rural development, the Swedish rural development programme, but also on the regional structural funds programmes, from 2000 to 2013. Another subject of interest is how policy makers understand rural tourism as presented in policy documents since these documents, to a great extent, direct programme spending in terms of projects and their content. This study is based on register data on programme spending, policy documents and programme evaluation reports. Results show that a relatively small amount of total public spending targets tourism - mainly going to accommodation, activities and marketing efforts - indicating that tourism is still not a prioritised area despite policy makers' understanding of rural tourism as expressed in policy documents. Thus, although public efforts target adequate parts of the tourism industry, they cannot be expected to contribute significantly to the restructuring of the rural economy.
\end{abstract}

Keywords: descriptive statistics, EU policy, rural development, Sweden, the new rural economy, tourism

Åsa Almstedt, Linda Lundmark \& Örjan Pettersson, Department of Geography and Economic History, Umeå University, SE-901 87 Umeå, Sweden. E-mail: asa. almstedt@umu.se,linda.lundmark@umu.se,orjan.pettersson@umu.se

\section{Introduction}

The restructuring of rural areas in Europe has in recent decades been prominent (Schmied 2005; Woods 2005, 2011; OECD 2006). Generally, it has meant that employment in traditional rural businesses such as agriculture and other natural resource activities has decreased. In many rural areas, the population composition has changed due to ageing and depopulation, which have also affected social structures. This causes structural problems in terms of further out-migration, unemployment and poor economic performance. The overall development in many European countries entails expanding metropolitan regions, with many rural regions lagging behind. However, territorial cohesion between regions within the European Union (EU) has been prioritised since all regions are seen as contributing to growth and welfare in Europe (Copus \& Hörnström 2011).

Tourism is often presented as a means to counteract this negative development as, in some instances, rural environments have been found to attract new inhabitants, tourists, entrepreneurs and businesses and, thus, can be considered a resource for increasing possibilities to live and work in rural areas (Findlay et al. 2000; Müller 2006). It is argued that tourism can attract in-migrants since it offers service-oriented jobs and opportunities to start businesses (Findlay et al. 2000; Paniagua 2002; Lundmark 2006; Lundmark et al. 2014). For this reason, an increased demand for rural amenities is 
seen as creating a more diversified labour market and contributing to the restructuring of the economy, from primary sector and manufacturing to a more service-oriented economy. This general transition has been observed in many rural areas throughout Europe and has been presented as a "new rural economy" (Hill 2005; Halseth et al. 2010; Shucksmith et al. 2011; Copus 2015). As a result, tourism has come to be seen as a universal tool for development in rural areas. One reason for this may be the perception of tourism as promising a high return on invested money, because the tourism sectors are characterised as providing cheap jobs and not requiring higher education (Lundmark 2006; Hall 2007). In line with EU recommendations, many member states have incorporated tourism measures into national rural and regional development programmes that are co-funded by the EU (Nylander \& Hall 2004; Woods 2011). However, tourism is no guarantee for economic development (e.g., Hall \& Jenkins 1998; Fleischer \& Felsenstein 2000; Hall 2007; Carson \& Carson 2011), and knowledge of how the tourism industry functions and which factors contribute to successful tourism among policy makers is of great importance.

The present study deals with the specific case of Sweden, where it is clear that rural tourism plays an important role in the corresponding policy documents (e.g., Government Offices of Sweden $2000,2007,2012)$. These documents are the result of a process where the responsible agencies consult stakeholders from the public, private and the voluntary sectors and have to be approved by the $\mathrm{EU}$. The process of forming these partnerships and developing the policy documents is not investigated in this article. Instead, we are interested in how public spending is distributed among various measures that promote tourism in rural areas. Potentially, this indicates policy makers' priorities and understanding of rural tourism.

Thus, the purpose of this study is to investigate the distribution of public spending on tourism in rural areas in Sweden. Its focus is on the main programme for rural development, the Swedish rural development programme, but also the regional structural funds programmes in place, from 2000 to 2013. Questions in focus are: what are the priorities regarding rural tourism in the programmes above; and, how is public spending distributed by sector and geographic location for measures promoting rural tourism? Policy documents have also been reviewed in order to investigate policy makers' understanding of rural tourism as presented in the documents since they, to a great extent, give direction to the programme spending in terms of projects and their content. Rural tourism, as defined in this paper, refers to tourism that takes place in rural areas. The study is based on register data on programme spending, policy documents and, to some extent, available programme evaluation reports. It should be noted that the intention of this study is not to evaluate the actual impact of policy. For such a study, more time would need to elapse to show the real effects of spending.

\section{Theoretical perspectives on regional development and policy in the EU}

General theoretical perspectives and key concepts related to regional development have influenced policies on territorial cohesion and rural development, not least within the EU and its member states (Woods 2005; Pike et al. 2006; Dax \& Kahila 2011; Tödtling 2011). Therefore, we introduce some of these aspects briefly before we move on to rural tourism more specifically.

Theories on regional development increasingly focus on endogenous growth processes and more recently - evolutionary perspectives (Hassink \& Klaerding 2011; Mackinnon \& Cumbers 2011). According to these views, key concepts for explaining regional development include agglomerations, clusters, knowledge, learning, creativity, innovation, social capital, entrepreneurship, institutions and path dependency (Sunley 2000; Pike et al. 2006).

European regional development policies have also been inspired by ideas about governance (Tödtling 2011). Governance implies a gradual movement away from direct state intervention (i.e., government) in order to stimulate development of 'softer' ways of promoting change. For example, this involves partnerships with numerous actors, both private and public, working in networks and frequently emphasising local/regional engagement and bottom-up perspectives. From an European perspective, this often includes ideas about multilevel governance, where actors on various geographical/administrative levels, from the EU to the very local level, participate and together contribute to achieving certain goals, such as sustainable development. Governance might give subnational levels more freedom to choose their way ahead, but also tends to place more responsibility on local 
and regional actors to manage their future. Presumably, one advantage is that regional and local strategies, to a larger extent, may consider their own circumstances and resources to stimulate development. Even though the ambition is to promote growth and cohesion throughout the EU, objections have been raised that such a strategy leads instead to widening gaps between different parts of the EU. It has been argued that this approach to regional development mainly benefits already strong regions, whereas lagging regions find it difficult to compete for EU funding and investments (Woods 2005; Schucksmith et al. 2011; Tödtling 2011; Wiberg 2013). No doubt, many rural areas in Europe have to handle structural disadvantages due to low population densities, long distances to more dynamic metropolitan areas and potential markets, poor transport infrastructure and path dependency based on traditional rural and natural resource sectors such as agriculture, forestry and mining (Woods 2005; Roto et al. 2014).

It should also be kept in mind that rural areas in Europe are heterogeneous with various conditions for development (Woods 2005; Copus \& Hörnström 2011). The heterogeneity and changed perceptions of rural areas and their development potentials have led to a shift in rural policy, from the top-down, subsidy-based policy targeting the agricultural sector to a multi-sectoral, place-based policy acknowledging the varying development potentials of rural areas, referred to as "the new rural paradigm" (OECD 2006). Behind this shift are factors such as an increased focus on amenities, pressures to reform agricultural policy, and decentralisation trends in regional policy. One example is the EU's Common Agricultural Policy (CAP) which was complemented in the early $21^{\text {st }}$ century with a wider rural development policy (the second pillar) where not only rural challenges are in focus but also the opportunities rural areas offer, for example, regarding tourism, recreation, and environmental services (Dax \& Kahila 2011; Woods 2011). In Sweden, as in many other EU countries, the main policy instrument is the rural development programme, which is the focus of this study.

\section{Theoretical perspectives on rural tourism}

Tourism has frequently been launched as an alternative which potentially can contribute to more positive development that attracts visitors, in-migrants and investment, thus creating new employment and income opportunities in rural areas (Hall \& Jenkins 1998; Woods 2005; Lundmark 2006; Cawley 2010; Halseth et al. 2010; Woods 2011). Many rural areas also benefit from an increasing demand for authentic and unique experiences based on local amenities, such as the natural landscape, recreational activities, culture and heritage (Stolarick et al. 2010). However, expectations are often unrealistic with tourism perceived as an easy way to achieve economic development and restructuring (Hall \& Jenkins 1998; Hall 2007). Hall et al. (2009: 125) argue that the high expectations "manifest a certain lack of knowledge and understanding of tourism dynamics and the very nature of tourism", and are often based on the global economic importance of the tourism industry as a whole. However, global trends are not easily transferable to the rural local context (Saarinen 2007). For tourism to benefit rural regions as a whole, tourism planning needs to be integrated into regional and local development goals (Saarinen 2003). Nonetheless, tourism is often planned separately without considering overall social and economic development (Liu \& Liu 2009). There are also frequent misinterpretations and over-estimations of tourism's contribution to rural economies (Hall et al. 2009). This is particularly true for nature-based tourism which, according to Hall (2007: 29), "tends to be very small-scale, often highly seasonal, and fails to attract the large number of tourists characterised by mass pleasure tourism". Although such tourism development does not meet the expectations of big improvements, it could still be considered sufficient for some rural areas (Hall 2007). In a Swedish context, there are only a few local areas in the sparsely populated northern part where tourism has had a major impact on labour market change and population development. These are mainly ski resorts, whereas in the rest of this large area tourism has, so far, not led to a substantial restructuring of the local and regional economy (Pettersson \& Westholm 1998; Pettersson 2001; Lundmark 2005).

Some researchers point to the difficulties of developing tourism in certain places. For example, Müller (2013) argues that the greatest challenges to rural tourism are not tourism industry-related, but are factors such as rural depopulation, the decline of rural services and declining interest in rural areas. Another example is the difficulty of developing tourism to help diversify the economy in pe- 
ripheral areas traditionally dependent on exporting natural resources (staples) because of path dependency and institutional lock-in (Carson \& Carson 2011). This suggests that tourism development may not be suitable for all rural areas. For instance, Hall et al. (2003) stress that tourism is best suited as a complement in areas with a diverse and thriving rural economy as income and employment inequalities may be the result in areas with a weak economy. Nevertheless, governments continue to support tourism as a growth strategy, especially in areas where seemingly few other business alternatives exist (Hall \& Jenkins 1998; Fleischer \& Felsenstein 2000; Schmallegger \& Carson 2010).

In order for tourism to succeed a number of components are required. These include attractions, the promotion of tourism attractions and community, tourism infrastructure (roads, airports, trains, buses, water and power services, parking, signs, recreation facilities), services (restaurants, accommodation, other tourism-related businesses), and hospitality, i.e. how tourists are treated by tourism businesses and community residents (Wilson et al. 2001). It is also important to understand the tourist market and have the required skills and training in tourism (Wilson et al. 2001; Gunn \& Var 2002; Hall et al. 2003). Moreover, Wilson et al. (2001) stress the need to develop tourism packages which contain high-quality attractions and businesses that make tourists spend more money, stay longer and return. Other important factors are sufficient funds for tourism development, strategic planning, coordination and cooperation between entrepreneurs and businesses, and involvement/ support from the community and local government (Wilson et al. 2001). To conclude, nature, scenic landscape and other features are not enough to attract tourists; rather tourism must be seen as a system of dynamic interrelations among different functioning parts. Similarly, it must balance supply and demand (Gunn \& Var 2002).

\section{Rural tourism in Sweden}

Nature-based tourism is one of the most common forms of rural tourism in Sweden, especially in northern Sweden with its vast areas of forests and the Scandinavian mountain range (Müller 2013). In farming areas, particularly in southern Sweden, farm-based tourism has given farmers new economic opportunities (e.g., farm-stays, farm shops with local food, hunting, horse riding) (Müller
2013). In terms of nature-based tourism, the economic value is often limited. In fact, it is indirect spending on various services that generates the most revenues in the area. Moreover, many entrepreneurs are lifestyle driven rather than financially motivated. Another challenge for nature-based tourism companies is the distance between the producer and the market (ibid.). A general obstacle to rural tourism is the limited supply of services and labour in sparsely populated areas (Waldenström \& Westholm 2009).

Investment in tourism facilities is affected by the difficulty rural businesses have getting access to capital; this makes public financial support essential (Müller 2013). Both the rural development programme and the regional structural funds programmes focused on in this study see tourism as an important potential contributor to rural development, and they financially support projects and enterprises that wish to develop new businesses and activities which are in line with the aim of the programmes. In addition, these programmes are important because projects require match funding from project applicants and thus have an impact on the allocation of public and private investments at local and regional levels.

\section{Methods and materials}

This study is mainly descriptive in character. It covers 16 development programmes in Sweden, part of EU policy, over two programme periods, 20002006 and 2007-2013. Two programmes belong to the rural development programme part of CAP (i.e., the Environmental and Rural Development Plan for Sweden 2000-2006, and the Rural Development Programme for Sweden 2007-2013) and the other 14 to the regional structural funds programmes which are part of the Cohesion policy (Table 1). The methods used are descriptive statistics based on the register data and review of policy documents and programme evaluation reports for the retrieval of data and general programme information.

The programmes' policy documents were reviewed to analyse how rural tourism is understood. This was accomplished by searching for paragraphs mentioning tourism and then compiling quotes regarding rural tourism. Data on public spending are based on register data for the Rural Development Programme for 2007-2013, and programme evaluation reports to the other programmes. Access to register data made it possible 
Table 1. Regional structural funds programmes in Sweden, 2000-2006 and 2007-2013. Swedish names are in brackets.

\begin{tabular}{l|l}
\hline $\mathbf{2 0 0 0 - 2 0 0 6}$ & $\mathbf{2 0 0 7 - 2 0 1 3}$ \\
\hline & North Sweden (Övre Norrland) \\
Objective 1 Programme for Norra Norrland & Mid-North Sweden (Mellersta Norrland) \\
Objective 1 Programme for Södra Skogslän & North Mid-Sweden (Norra Mellansverige) \\
Norra region Objective 2 Programme & East Mid-Sweden (Östra Mellansverige) \\
Västra region Objective 2 Programme & Stockholm \\
Öarna region Objective 2 Programme & Småland and the islands (Småland och Öarna) \\
Södra region Objective 2 Programme & West Sweden (Västsverige) \\
& Skåne-Blekinge \\
\hline
\end{tabular}

to analyse the distribution of spending in more details. Corresponding data were not available for the other programmes and, consequently, more emphasis has been placed on the Rural Development Programme for 2007-2013. As a result, geographical and sector distribution is based solely on the Rural Development Programme for 20072013, whereas the estimation of public spending is based on all programmes where these data exist. However, for most of the regional structural funds programmes for 2000-2006, the information is comparatively poor. This is because tourism efforts have been incorporated into broader measures and, thus, are not distinguishable.

The register data are derived from a database compiled by the Swedish Board of Agriculture (SBA) containing information on each project and enterprise that received support from the European Agricultural Fund for Rural Development. There are two kinds of support available. Enterprise support targets individual enterprises (mainly for investments in infrastructure and purchases of external services). Project support targets groups of enterprises, organisations, associations, etc. "where the benefit of the activity reaches more parties than just the applicant(s)" (mainly enables development activities such as marketing, the promotion of local development opportunities, and research collaborations) (Government Offices of Sweden 2008: 203). The variables of relevance for this study include project title, name of grant receiver, geographic coordinates, granted amount of funds, measure code, category (the field of activity), subcategory, and "tourism activities (yes/no)". The last variable denotes which projects and enterprises outside of the main tourism measure ("promoting the tourist industry", measure code 313 ) relate to tourism. For example, micro-enterprises with tourism activities ("business development in micro-enterprises", code 312) and projects to increase a place's attractiveness ("village renewal and development", code 322) were used by SBA when retrieving data to meet our request for rural tourism data. Thus, public spending also includes data for tourism-related measures. Most of these data belong to the programme objective "diversification and a better quality of life in rural areas" (under axis 3 , one of the four thematic axes corresponding to the objectives of rural development policy). It also includes the LEADER (i.e., a bottom-up approach to rural development which in 2007-2013 was part of the Rural Development Programme) projects involving tourism. Measures that indirectly benefit tourism, such as environmental measures, are not included in this study. To analyse distributed spending by sector and geographic location, data for measure code 313 are the most complete and, thus, we focus on them. A limitation is that geographic coordinates indicate the location of the grant receiver which, in a few cases, differs from the location of the actual project. However, for enterprise support the location of the grant receiver generally coincides with the location of the enterprise. By the term 'sector' we mean the various fields of activity in rural tourism, such as accommodation and tourist activities (e.g., fishing, hiking).

Some clarifications need to be made. Public spending, as it relates to this study, consists of EU funds and the national funding required by the EU. The register data received from SBA and the data for most of the other programmes only show EU funds. However, since we are more interested in 
the proportions rather than the exact amount of public spending, we present national funding as a percentage of total project/enterprise spending according to policy documents. Also, these data show granted funds rather than paid out funds. Potentially, these numbers may differ somewhat if repayment has been demanded. Nonetheless, we consider using data for granted funds relevant, especially considering that payment for 2007-2013 was not yet completed when conducting the study. The discrepancy using data for granted funds should be less than that which would be caused using data for paid out funds. It is possible that granted funds better represent policy makers' ambitions and priorities than paid out funds. Moreover, estimating public spending on rural tourism is complex because of the many programmes involved and the varying scope of data. Therefore, all the results presented below should be considered as indications rather than exact measures.

We begin by presenting the statements about rural tourism found in policy programmes so as to illustrate policy makers' understanding of rural tourism. We then analyse public spending on rural tourism within these programmes in relation to other focus areas such as agriculture and innovation. This indicates policy makers' priorities regarding rural tourism. Thereafter, distribution by sector and geographic location is presented, focusing on the Rural Development Programme for 2007-2013.

\section{The understanding of rural tourism in policy documents}

The investigated policy documents generally describe rural tourism in positive terms and emphasise its ability to generate economic growth, especially for the 2007-2013 period. For example, the policy document guiding the regional structural funds programmes for 2007-2013 states:

\begin{abstract}
"The tourism industry has come to play an increasingly important role in sustainable growth in many regions. A successful tourism industry not only generates jobs within tourism businesses, but also leads to essential business developments, services and employment in other areas. Tourism is particularly important to rural and sparsely populated areas of significant natural and cultural value" (Government Offices of Sweden 2007: 16-17).
\end{abstract}

A similar statement in the policy document for the Rural Development Programme for 2007-
2013 emphasises tourism's growth potential, employment opportunities and favourable impact on other local businesses (Government Offices of Sweden 2008). In this policy, tourism is regarded as one of the priority areas under "new production of goods and services" and part of "food production with added value", both of which are regarded as nationally-prioritised development areas; the latter being associated with the vision "Sweden the new culinary nation" (ibid.).

Quotes such as "visits to natural attractions, handicraft centres, manufacturing sites and events have grown in popularity faster than the average rate for tourism around the country" and "it has become increasingly important for enterprises wishing to remain competitive in the market to offer interesting or exciting experiences and other activities" are part of the reasoning behind the tourism measure (code 313) (Government Offices of Sweden 2008: 212). Activities such as staying on a farm, horse riding, culinary experiences and various activity packages are described as "market concepts that have developed well and are attracting growing numbers of visitors" (ibid.: 212). The document also specifies what is needed for rural tourism to develop successfully, as illustrated in the following quote:

"Package deals or other combinations of travel, accommodation, food, activities and experiences are increasingly in demand from customers. Success in this area calls for a thorough knowledge of the business and quality products. Accessibility and logistical solutions for travel and transport are other factors of importance for the development of tourism in rural areas" (ibid.: 212).

Other components that are emphasised and described as "crucial to the proper realization of the area's development potential" are cooperation between tourist enterprises at local and regional levels in terms of product development, marketing and logistics, and "greater professionalism and competence in the industry" (ibid.: 213).

In older programmes, tourism is also acknowledged as contributing to the local economy, but is less emphasized, which suggests a more moderate view of tourism. For example, the Environmental and Rural Development Plan for 2000-2006 states:

"Tourism is a growing branch within the services sector which has increased in economic importance. Service is a product which is consumed where it is produced, which means that rural tour- 
ism could be of increasing significance for the rural economy if it is used in the right way" (Government Offices of Sweden 2000: 228).

Thus, given the understanding of rural tourism presented above, the expectation would be that a considerable amount of public funds would be spent on rural tourism.

\section{Public spending on rural tourism}

Public spending on rural tourism takes place foremost within the rural development programme. This programme relates to small and micro enterprises with clear links to agriculture, forestry and the wider rural development at the local level. For large-scale investments and more strategic projects, regional development programmes apply. One example is cooperation efforts regarding destination development (Government Offices of Sweden 2008; SAERG 2011). As already indicated, it was not possible to estimate the total amount of public spending on rural tourism for the regional structural funds programmes for 2000-2006 because of lack of data. However, estimates were possible for the two programmes covering northern Sweden. The Objective 1 programme for Norra Norrland was granted approx. SEK 270 million in EU funds (EUR 1 = SEK 9), plus additional national public funding (the total programme budget comprised: EU funds SEK 3.7 billion, and national public funds SEK 2.8 billion). The Norra region Objective 2 Programme was granted approx. SEK 370 million plus national public funding (total budget: EU funds SEK 1.6 billion and national public funds SEK 2.5 billion). The relatively large proportion of money spent on tourism in northern Sweden may be explained to some extent by the region's long tradition of tourism based on its nature, parts of which are referred to as Europe's last wilderness (County Administrative Board of Norrbotten 2010). The trend continues in subsequent programmes, i.e. the regional structural funds programmes for 2007-2013. As Table 2 shows, the two programmes covering the northern part of Sweden (i.e., "North Sweden" and "Mid-North Sweden") spend a bigger share of their budgets on tourism than the rest of the programmes together. In fact, in the "Mid-North Sweden" programme, tourism is declared a key industry. This is the only programme with tourism as a separate effort area ("1.3 Tourism and the experience industry") (SAERG 2011). In contrast, three programmes spent no money on tourism (i.e., "North Mid-Sweden", "East MidSweden" and "West Sweden").

In total for all individual programmes, tourism was granted almost SEK 514 million from EU funds. This is six per cent of the total support granted to the programmes (approx. SEK 8.5 billion) (SAERG 2013). National public funding (i.e., $50 \%$ of total public spending for "North Sweden", "Mid-North Sweden" and "Skåne-Blekinge", and 60\% for Stockholm and Småland and the islands) is added to this. This makes tourism the third biggest priority area just before "information society" (5.7\%), but after "research and technological development, innovation and entrepreneurship" (66\%) and "transport investments" (15.2\%) (SAERG 2013). This clearly demonstrates that tourism is a prioritised area; however, in terms of funding, it is small when compared with investments in research and development $(R \& D)$ and transportation.

Table 2. Granted tourism support in the regional structural funds programmes, 2007-2013 (source: SAERG 2013).

\begin{tabular}{l|l|l}
\hline $\begin{array}{l}\text { Regional structural funds programmes, } \\
\mathbf{2 0 0 7 - 2 0 1 3}\end{array}$ & $\begin{array}{l}\text { Tourism support, EU funds (million } \\
\text { SEK), Jan 1, 2007 - June 30, 2013 }\end{array}$ & Share of programme budget (\%) \\
\hline North Sweden & 216.3 & 9.6 \\
Mid-North Sweden & 233.7 & 14.7 \\
North Mid-Sweden & 0 & 0 \\
East Mid-Sweden & 0 & 0 \\
Stockholm & 11.5 & 3.5 \\
Småland and the islands & 28.2 & 4.5 \\
West Sweden & 0 & 0 \\
Skåne-Blekinge & 23.9 & 3.7 \\
Total & 513.6 & 6.0 \\
\hline
\end{tabular}

Note: Although the data do not cover the full programme period all decisions on granted support were already made within this period. 
Within the Environmental and Rural Development Plan for 2000-2006, approx. SEK 85 million was granted to rural tourism and at least SEK 31 million to tourism-related activities, including national public funding (Table 3). Substantially more money, approx. SEK 810 million, was allocated to rural tourism in the Rural Development Programme for 2007-2013, including tourism related measures. National public funding $(54.19 \%$ for enterprise and project support, and $60 \%$ for LEADER projects) is added to this.

Looking at the programme period 2007-2013, the budget for axis 3 ("diversification and a better quality of life in rural areas"), which includes the tourism measure "promoting the tourist industry" (code 313), was SEK 3.7 billion including national public funding. This is approx. $10 \%$ of the total budget. This can be compared to SEK 5.7 billion for axis 1 ("improving competitiveness in the agricultural and forestry sector", approx. $16 \%$ of total budget), SEK 23.3 billion for axis 2 ("improving the environment and the landscape", approx. 64\% of total budget), and SEK 2.4 billion for axis 4 ('LEADER', approx. 7\% of total budget) (Government Offices of Sweden 2012). ${ }^{1}$ According to the policy document, the budget for code 313 is SEK 625 million including national public funding, which is $1.7 \%$ of the total budget (ibid.). Although these data do not exactly match the register data from SBA, they indicate the proportions. Once again, in policy programmes, tourism is stated as being important for rural development. However, in terms of actual spending, it is obvious that a substantial amount of funding goes more or less directly to the agricultural sector (the main targets in axis 1 and axis 2), whereas tourism development receives a comparatively small amount.

\section{Distribution of public spending}

\section{Distribution by sector}

In terms of enterprise support, a total of SEK 238 million was distributed to 818 enterprises, i.e. on average SEK 291,000 per enterprise (Table 4). The biggest sector is 'accommodation', which received nearly $60 \%$ of the total enterprise support. A significant share of this went to small-scale accommodation under the sub-categories "cabins, rental" (SEK 46 million) and "B\&B, boarding house" (SEK 16 million). The second biggest sector is "nature, hunting, fishing, outdoor recreation" (17\% of enterprise support), followed by "food including food tourism" (13\% of enterprise support). In comparison, "culture, history, amusement" was granted about 3\% of enterprise support, which suggests that this is not a prioritised focus area within the programme.

In terms of project support, a total of SEK 286 million was distributed to 493 projects, i.e. on average SEK 579,000 per project (Table 5). The biggest sector is "nature, hunting, fishing, outdoor recreation", which received nearly $31 \%$ of total project support, followed by "general development/marketing" (27\%), and "culture, history, amusement" (18\%). Thus, compared to enterprise support, no single dominant sector exists.

An analysis of the distribution of public spending by sector shows that emphasis varies be-

Table 3. Granted tourism support in the rural development programme, 2000-2006 and 2007-2013.

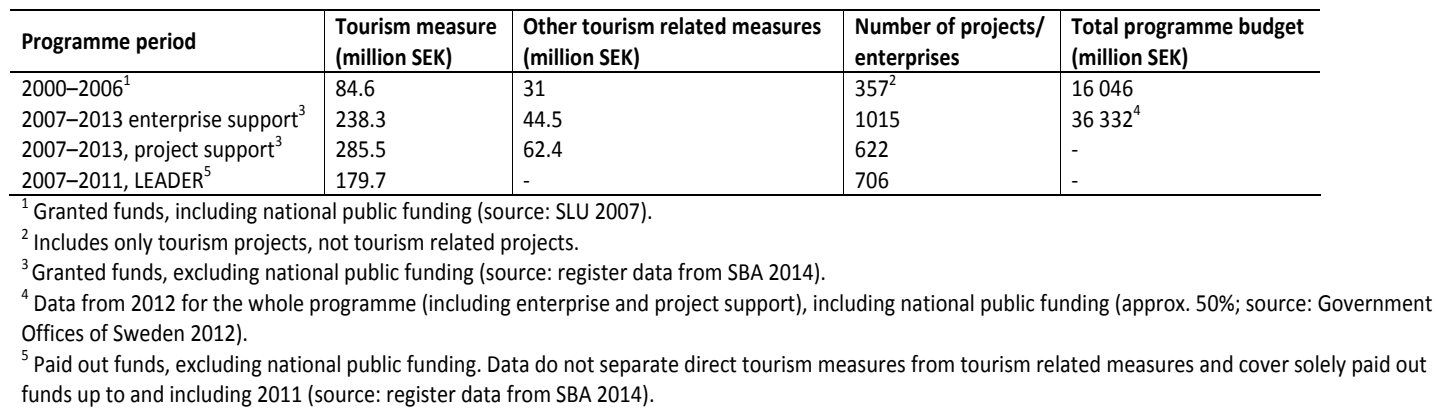


Table 4. Granted enterprise support for rural tourism (measure code 313) in the Rural Development Programme for 20072013 (source: register data from SBA 2014).

\begin{tabular}{l|l|l|l}
\hline Sector & $\begin{array}{l}\text { Number of } \\
\text { enterprise support }\end{array}$ & $\begin{array}{l}\text { Granted funds } \\
\text { (million SEK) }\end{array}$ & $\begin{array}{l}\text { Share of total } \\
\text { enterprise support (\%) }\end{array}$ \\
\hline Accommodation & 418 & 142.6 & 59.8 \\
Nature, hunting, fishing, outdoor recreation & 177 & 40.0 & 16.8 \\
Food incl. food tourism & 107 & 30.8 & 12.9 \\
Other' & 47 & 9.5 & 4.0 \\
Horses incl. equestrian tourism & 44 & 8.7 & 3.7 \\
Culture, history, amusement & 25 & 6.8 & 2.8 \\
Total & 818 & 238.3 & 100.0 \\
\hline ''Other' includes the categories "retail shops", 'handicraft', "sports/exercise", "manufacturing/services etc.", "general \\
development/marketing", and 'other'.
\end{tabular}

Table 5. Granted project support for rural tourism (measure code 313) in the Rural Development Programme for 2007-2013 (source: register data from SBA 2014).

\begin{tabular}{l|l|l|l}
\hline Sector & $\begin{array}{l}\text { Number of project } \\
\text { support }\end{array}$ & $\begin{array}{l}\text { Granted funds } \\
\text { (million SEK) }\end{array}$ & $\begin{array}{l}\text { Share of total project } \\
\text { support (\%) }\end{array}$ \\
\hline Nature, hunting, fishing, outdoor recreation & 131 & 87.5 & 30.6 \\
General development/marketing & 125 & 76.3 & 26.7 \\
Culture, history, amusement & 109 & 51.3 & 18.0 \\
Food including food tourism & 60 & 39.4 & 13.8 \\
Horses incl. equestrian tourism & 24 & 9.8 & 3.4 \\
Accommodation & 18 & 7.9 & 2.8 \\
Sports/exercise & 14 & 7.8 & 2.7 \\
Other & 12 & 5.6 & 2.0 \\
Total & 493 & 285.5 & 100.0 \\
\hline
\end{tabular}

' 'Other' includes the categories 'handicraft', "manufacturing/services etc.", and 'other'.

tween enterprise support and project support. For example, considerably more enterprise support is directed towards 'accommodation', SEK 142 million compared to nearly SEK 8 million of project support and SEK 76 million of project support was directed towards "general development/marketing" compared to only SEK $1.6 \mathrm{mil}$ lion of enterprise support (part of 'Other'). This difference may be explained by the character of each support type. Project support focuses mainly on enabling development activities (e.g., marketing, research collaborations) while enterprise support mainly goes to investments in physical infrastructure (e.g., building cabins, trails, improved access to attractions) (Government Offices of Sweden 2008).

Thus, the allocation of funding to sectors largely corresponds with many of the components needed for rural tourism to succeed (e.g., Wilson et al. 2001). For example, accommodation is part of the basic services for tourists, marketing is part of promotion, and several of the sectors (e.g., nature, culture, horses, food, sports) relate to various attractions.

\section{Geographical distribution}

The funding for tourism in the Rural Development Programme for 2007-2013 (code 313) goes to either enterprise support or project support. The map in Figure 1 indicates that municipalities located in regions with traditional tourism destinations were often granted the highest amounts of enterprise support; these include the west coast close to Gothenburg, areas nearby Stockholm, the south-eastern coast, Gotland, areas close to Norway and areas in the northernmost Sweden. For example, the highest amount of enterprise support was granted to Kiruna, Sweden's northernmost municipality which already has a diversified tourism industry based on, for example, its vast wilderness areas, the Sami culture, mining and the ice hotel in Jukkasjärvi. 
This suggests in general that areas with already established tourism enterprises receive the most public funding and, presumably, this strengthens their relative position. Nevertheless, many other rural areas also receive enterprise support. This might reflect priorities within regions and/or a tradition in these areas of applying for funds.

With regard to distribution per capita, it seems that the highest values are to be found in areas with relatively small populations such as in northern Sweden. Conversely, it should be noted that one of the counties in northern Sweden, Västerbotten County, did not grant enterprise support to tourism because of a decision made at the regional level (County Administrative Board of Västerbotten 2011).

The distribution of project support shows three distinct regions with the highest amount of granted support: the metropolitan regions of Stockholm and Malmö, and the Scandinavian mountain range, especially the Östersund region (Fig. 2). In addition, Gotland and parts of the mountain area in the Västerbotten County stand out, the latter both in terms of the amount of funds granted and per capita. This includes the municipality of Storuman, the location of the Hemavan/Tärnaby ski re-

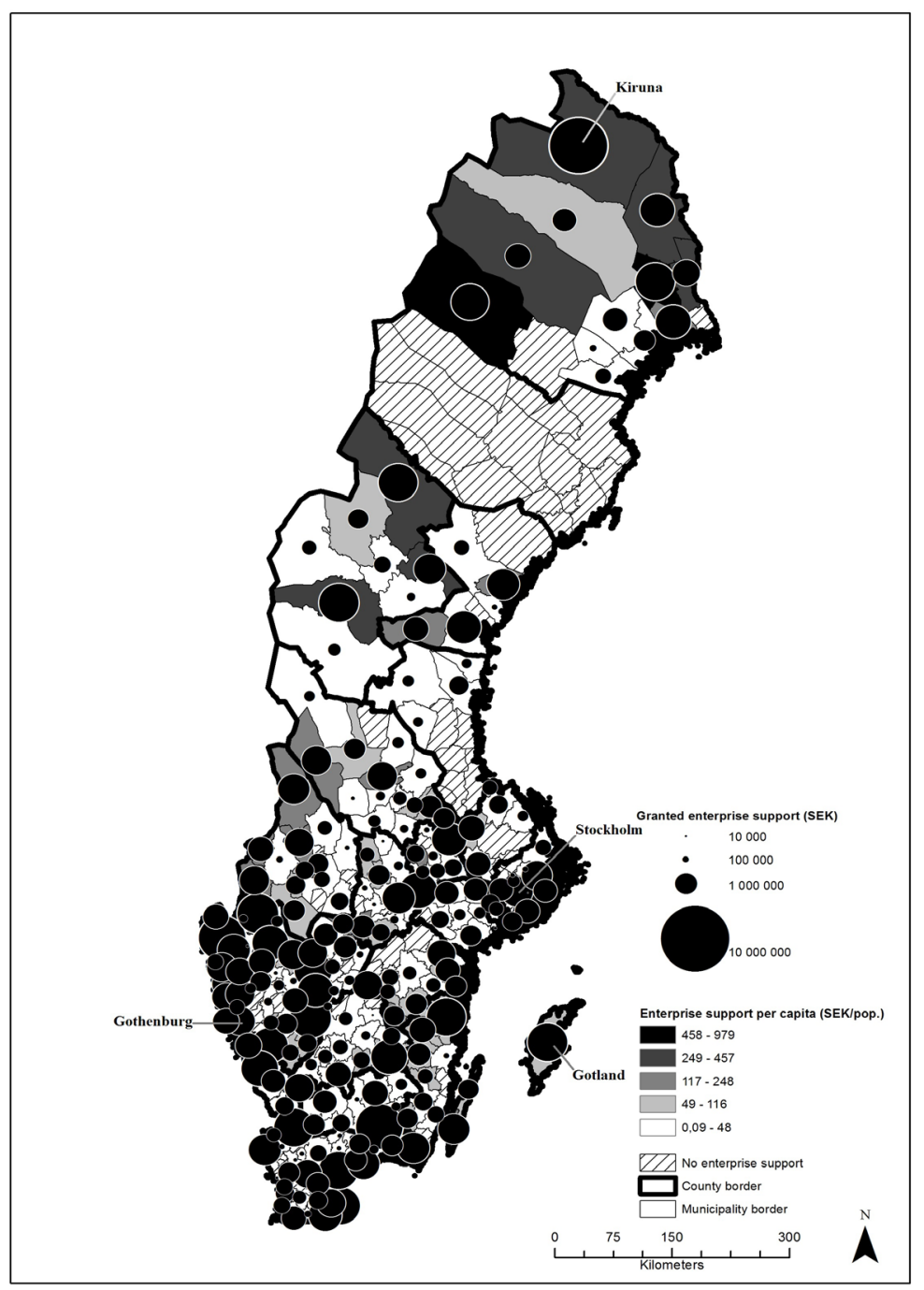

Fig. 1. Distribution of granted enterprise support for rural tourism (measure code 313) in the Rural Development Programme for 2007-2013 at the municipal level, and amount of granted enterprise support per capita (source: register data from SBA 2014). 
sort. Consequently, it suggests that project money, at least in some cases, is being channelled into areas already undergoing restructuring into tourism as mentioned earlier (e.g., Pettersson \& Westholm 1998; Lundmark 2005).

However, since data on project support reflect the location of the grant receiver, which, as already noted, may differ from the location of the project, the resulting pattern is slightly misleading. For example, the head offices of several organisations applying for funds are in Stockholm and, thus, the coordinates give the position of Stockholm even though project names or de- scriptions reveal that the projects target other areas in Sweden.

\section{Concluding remarks}

This paper set out to answer questions on the priorities of rural development and regional structural funds programmes regarding rural tourism, and how public money is distributed by sector and geographic location for measures that promote rural tourism in Sweden. A review of relevant policy programmes indicates that policy makers have

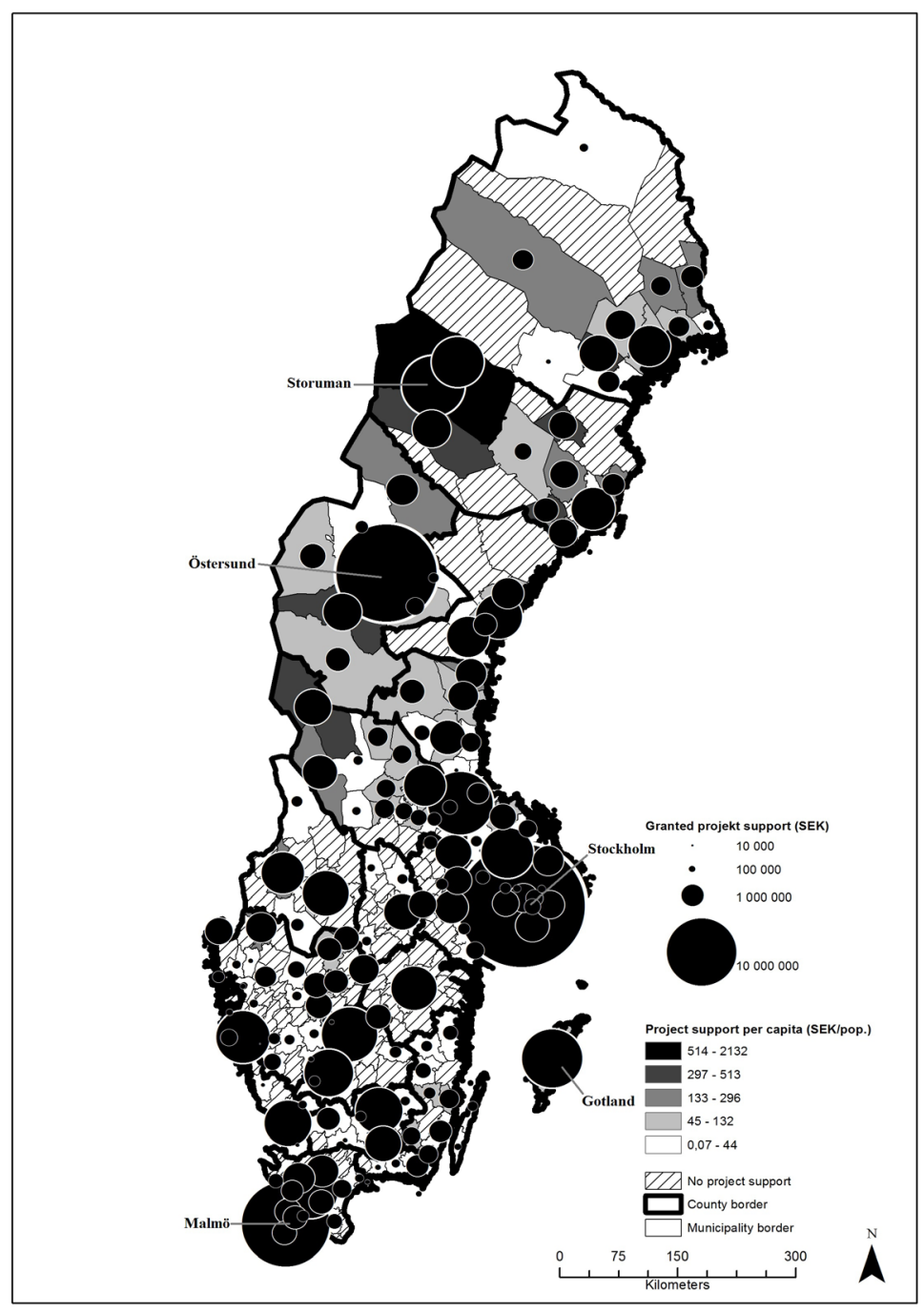

Fig. 2. Distribution of granted project support for rural tourism (measure code 313) in the Rural Development Programme for 2007-2013 at the municipal level, and amount of granted project support per capita (source: register data from SBA 2014). 
general knowledge of product supply and demand concerning rural tourism, at least on paper. For instance, they acknowledge the demand for experience-based activities (e.g., food tourism, equestrian tourism), the need for activity packages to attract tourists, the importance of knowledge of the tourism business and greater professionalism, and also the role small businesses play in the development of rural areas. However, given the understanding of rural tourism in the policy documents, we would expect a higher emphasis on tourism in the actual spending. Instead data on spending reveal that tourism is not a highly prioritised area. In fact, the actual amount of money granted to rural tourism is relatively small, at least when compared to support targeted at sectors such as agriculture in the rural development programme and research/ innovation/entrepreneurship and transport investments in the regional structural funds programmes. Of course, investment in transport infrastructure is comparatively costly and may, in some cases, also indirectly benefit the tourism sectors. It is obvious that the rural development programme mainly supports traditional rural sectors such as agriculture and forestry, whereas tourism receives much less public funding. This corresponds with more general tendencies within the EU where the agricultural sector still receives a major share of the overall funding for rural development; this might also reflect a kind of institutional conservatism (Dwyer et al. 2007; Dax \& Kahila 2011). Altogether, this gives the impression that tourism is not as highly prioritised as is often stated in policy programmes. The relatively small amount of public funding granted to rural tourism, especially when compared with the financial resources going to the agricultural sector, leads to the conclusion that expectations about the restructuring of the rural economy promoting tourism should be somewhat moderated. However, this coincides with a general perception among decision-makers that tourism is an "easy path to economic development and restructuring" (Hall \& Jenkins 1998: 38).

The actual distribution of funding by sector and geographic location was also investigated for the Swedish Rural Development Programme for 2007-2013. Distribution by sector indicates that many of the sectors relate to the components needed for rural tourism to succeed (e.g., Wilson et al. 2001), for example accommodation, activities, marketing and packaging. This suggests that policy makers, at least to some extent, understand what is needed for rural tourism to become suc- cessful. On the other hand, the pattern of the geographical distribution is less clear. When it comes to enterprise support, there is a tendency for traditional tourism destinations along the coasts and in mountain areas to attract most grants, whereas for project support five areas stand out (i.e., the Stockholm and Malmö metropolitan regions, the Östersund region, the Västerbotten mountain area and Gotland). Nonetheless, apart from these trends, public spending is also allocated to rural areas in many other parts of Sweden. This reinforces the impression that tourism is often seen as a tool for development in all rural areas, irrespective of the specific preconditions in these areas, and even though researchers have claimed that tourism may not be suitable for all rural areas (e.g., Hall et al. 2007; Carson \& Carson 2011). This might reflect lack of alternative ideas as to how to stimulate development in rural areas facing general depopulation, structural unemployment and generally poor conditions (e.g., Müller \& Jansson 2007).

Finally, as this paper demonstrates, lack of tourism data prevents a more detailed analysis. To evolve the field of tourism research and public spending, there is a need for more detailed (e.g., no missing data for certain variables) and comparable data between programme periods so that more encompassing evaluations can be made. The responsibility for the collection of such basic information rests firmly with the responsible authorities. Data should be easily accessible and transparent to users, and included variables should be developed in cooperation with users and researchers.

\section{NOTES}

${ }^{1}$ Technical support is also included in the programme budget (SEK 1.2 billion, approx. 3\%).

\section{REFERENCES}

Carson DA \& Carson DB 2011. Why tourism may not be everybody's business: the challenge of tradition in resource peripheries. The Rangeland Journal 33: 4, 373-383. http://dx.doi.org/10.1071/RJ11026.

Cawley M 2011. Adding value locally through integrated rural tourism: lessons from Ireland. In Halseth G, Markey S \& Bruce D (eds). The next rural economies: constructing rural place in global economies, 89-101. CABI Publishing, Wallingford.

Copus AK 2015. The new rural economy and macroscale patterns. In Copus AK \& de Lima P (eds). Territorial cohesion in rural Europe: the relational 
turn in rural development, 11-34. Routledge, Oxon.

Copus AK \& Hörnström L (eds) 2011. The new rural Europe: towards rural cohesion policy. Nordregio Report 2011:1. Nordregio, Stockholm. <http:// www. nordregio.se/Publications/Publications-2011/The-New-Rural-Europe-Towards-Rural-Cohesion-Policy/> 14.01.2015.

County Administrative Board of Norrbotten 2010. Objective 1 Norra Norrland Sweden: final report 2000-2006. The County Administrative Board of Norrbotten, Luleå. <http://www.lansstyrelsen. se/norrbotten/SiteCollectionDocuments/Sv/omlansstyrelsen/eu-ochinternationellt/Slutrapport $\% 20 M \%$ C3\% A51\%201\%20NN\%20201002-18.pdf> 17.06.2014. (In Swedish)

County Administrative Board of Västerbotten 2011. Regional implementation strategy for the rural development programme 2007-2013 Västerbotten county. Revised version 2011-02-01. The County Administrative Board of Västerbotten, Umeå. <http://www.lansstyrelsen.se/vasterbotten/SiteCollectionDocuments/Sv/lantbruk-ochlandsbygd/landsbygdsutveckling/Landsbygdsprogram/Genomf\% C3\% B6randestrategi\% 20 f\% C 3\% B 6r\% 20 Landsbygdsprogrammet $\% 20$ i\%20V\% C3\%A4sterbotten\%202007-2013.pdf> 17.06.2014. (In Swedish)

Dax T \& Kahila P 2011. Policy perspective - The evolution of EU rural policy. In Copus AK \& Hörnström L (eds). The new rural Europe: towards Rural Cohesion Policy, 87-106. Nordregio Report 2011:1. Nordregio, Stockholm. <http://www. nordregio.se/Publications/Publications-2011/ The-New-Rural-Europe-Towards-Rural-CohesionPolicy/> 14.01.2015.

Dwyer J, Ward N, Lowe P \& Baldock, D 2007. European rural development under the Common Agricultural Policy's 'second pillar': institutional conservatism and innovation. Regional Studies 41: 7, 873-887. http://dx.doi.org/10.1080/00343400601142795.

Findlay AM, Short D \& Stockdale A 2000. The labourmarket impact of migration to rural areas. Applied Geography 20: 4, 333-348.

http://dx.doi.org/10.1016/S0143-6228(00)00012-6.

Fleischer A \& Felsenstein D 2000. Support for rural tourism: does it make a difference? Annals of Tourism Research 27: 4, 1007-1024.

http://dx.doi.org/10.1016/S0160-7383(99)00126-7.

Government Offices of Sweden 2000. Environmental and rural development plan for Sweden 2000-2006. <http://www.government.se/content/1/c6/02/60/93/0d313d0c.pdf> 17.06 .2014 .

Government Offices of Sweden 2007. A national strategy for regional competitiveness, entrepreneurship and employment 2007-2013. <http:// $w w w . g o v e r n m$ ent. se / content/1/ c6/07/74/17/1fdb10a6.pdf> 17.06.2014.

Government Offices of Sweden 2008. Rural development programme for Sweden 2007-2013. <http://www.government.se/content/1/ c6/08/27/27/ee703769.pdf> 17.06.2014.

Government Offices of Sweden 2012. Rural development programme for Sweden 2007-2013. Version 2012. (In Swedish)

Gunn CA \& Var T 2002. Tourism planning: basics, concepts, cases. Routledge, London.

Hall CM 2007. North-south perspectives on tourism, regional development and peripheral areas. In Müller DK \& Jansson B (eds). Tourism in peripheries: perspectives from the far north and south, 19-37. CABI, Wallingford.

Hall CM \& Jenkins JM 1998. The policy dimensions of rural tourism and recreation. In Butler R, Hall $\mathrm{CM}$ \& Jenkins J (eds). Tourism and recreation in rural areas, 19-42. Wiley, Chichester.

Hall CM, Müller DK \& Saarinen J 2009. Nordic tourism: issues and cases. Channel View Publications, Bristol.

Hall D, Mitchell M \& Robert L 2003. Tourism and the countryside: dynamic relationships. In Hall D, Roberts L \& Mitchell M (eds). New directions in rural tourism, 3-15. Ashgate, Aldershot.

Halseth G, Markey S \& Bruce D 2010. The next rural economies: constructing rural place in global economies. CABI Publishing, Wallingford.

Hassink R \& Klaerding C 2011. Evolutionary approaches to local and regional development policy. In Pike A, Rodríguez-Pose A \& Tomaney J (eds). Handbook of local and regional development, 139-148. Routledge, London.

Hill B 2005. The new rural economy: change, dynamism and government policy. The Institute of Economic Affairs, London.

Liu A \& Liu H 2009. Government approaches to tourism: an international inquiry. International Journal of Tourism Policy 2: 3, 221-238.

http://dx.doi.org/10.1504/IJTP.2009.024554.

Lundmark L 2005. Economic restructuring into tourism in the Swedish mountain range. Scandinavian Journal of Hospitality and Tourism 5: 1, 23-45. http://dx.doi.org/10.1080/15022250510014273.

Lundmark L 2006. Restructuring and employment change in sparsely populated areas: examples from northern Sweden and Finland. Doctoral dissertation. Department of Social and Economic Geography, Umeå University, Umeå, Sweden.

Lundmark L, Ednarsson M \& Karlsson S 2014. International migration, self-employment and restructuring through tourism in sparsely populated areas. Scandinavian Journal of Hospitality and Tourism 14: 4, 422-440. http://dx.doi.org/10.1080/15022250.2014.967995.

Mackinnon D \& Cumbers A 2011. Introduction to economic geography: globalization, uneven development and place. Pearson Prentice Hall, Harlow.

Müller DK 2006. Amenity migration and tourism development in the Tärna mountains, Sweden. In Moss LAG (ed). Amenity migrants: seeking and sustaining mountains and their cultures, 245-248. CABI, Wallingford. 
Müller DK 2013. Sweden. In Fredricsson C \& Smas L (eds). Small-scale tourism in rural areas: trends and research in Nordic countries, 41-46. Nordic Working group 1B: future rural areas. Nordregio Working paper 2013:3. Nordregio, Stockholm. <http://www.nordregio.se/en/Publications/Publications-2013/Small-scale-Tourism-in-Rural-Areas/>17.06.2014.

Müller DK \& Jansson B 2007. The difficult business of making pleasure peripheries prosperous: perspectives on space, place and environment. In Müller DK \& Jansson B (eds). Tourism in peripheries: perspectives from the far north and south, 3-18. $\mathrm{CABI}$, Wallingford.

Nylander M \& Hall D 2004. Rural tourism policy: European perspectives. In Hall D, Kirkpatrick I \& Mitchell M (eds). Rural tourism and sustainable business, 17-40. Channel View Publications, Clevedon.

OECD 2006. The new rural paradigm: policies and governance. OECD rural policy reviews. Organisation for Economic Co-Operation and Development, Paris.

Paniagua A 2002. Urban-rural migration, tourism entrepreneurs and rural restructuring in Spain. Tourism Geographies 4: 4, 349-371. http://dx.doi.org/10.1080/14616680210158128.

Pettersson Ö 2001. Microregional fragmentation in a Swedish county. Papers in Regional Science 80: 4, 389-409. http://dx.doi.org/10.1007/PL00013630.

Pettersson Ö \& Westholm E 1998. Fattigfickor och gräddhyllor: en mikroregional analys av välfärdens geografiska fördelning i Dalarna. Dfr-rapport 1998:1. Dalarnas forskningsråd, Falun. (In Swedish)

Pike A, Rodríguez-Pose A \& Tomaney J 2006. Local and regional development. Routledge, London.

Roto J, Grunfelder J \& Rispling L (eds) 2014. State of the Nordic region 2013. Nordregio report 2014: 1. Nordregio, Stockholm.

Saarinen J 2003. The regional economics of tourism in Northern Finland: the socio-economic implications of recent tourism development and future possibilities for regional development. Scandinavian Journal of Hospitality and Tourism 3: 2, 91-113. http://dx.doi.org/10.1080/15022250310001927.

Saarinen J 2007. Tourism in peripheries: the role of tourism in regional development in northern Finland. In Müller DK \& Jansson B (eds). Tourism in peripheries: perspectives from the far north and south, 41-52. CABI, Wallingford.

SAERG 2011. Regional structural funds programme for regional competitiveness and employment in Mid-North Sweden 2007-2013. Revised operational programme. Swedish Agency for Economic and Regional Growth, Stockholm. (In Swedish)

SAERG 2013. A collected progress report by 201310-25: an investment for the future. The European
Regional Development Fund, programme period 2007-2013. Dnr. 6.1.15-2013-4202. Swedish Agency for Economic and Regional Growth, Stockholm. <http://www.tillvaxtverket.se/download/18.e8f46b8140a162b4fe40e4/1383223361 095/20131025+Rapport.pdf> 03.04.2014. (In Swedish)

Schmallegger D \& Carson D 2010. Is tourism just another staple? A new perspective on tourism in remote regions. Current Issues in Tourism 13: 3, 201-221.

Schmied D (ed) 2005. Winning and losing: the changing geography of Europe's rural areas. Ashgate, Aldershot.

Shucksmith M, Talbot H \& Lee R 2011. Meta-narratives as heuristic generalisations of rural change. In Copus AK \& Hörnström L (eds). The new rural Europe: towards rural cohesion policy, 19-36. Nordregio Report 2011:1. Nordregio, Stockholm. <http://www.nordregio.se/Publications/Publications-2011/The-New-Rural-Europe-Towards-Rural-Cohesion-Policy/> 14.01.2015.

Stolarick K, Denstedt M, Donald B \& Spencer GM 2010. Creativity, tourism and economic development in a rural context: the case of Prince Edward County. Journal of Rural and Community Development 5: 1/2, 238-254. <http://www.jrcd.ca/ viewarticle.php?id=397> 14.01.2015.

Sunley P 2000. Urban and regional growth. In Sheppard E \& Barnes TJ (eds). A companion to economic geography, 187-201. Blackwell, Oxford.

Tödtling F 2011. Endogenous approaches to local and regional development policy. In Pike A, Rodríguez-Pose A \& Tomaney J (eds). Handbook of local and regional development, 333-343. Routledge, London.

Waldenström C \& Westholm E 2009. The natural resource turn: challenges for rural research and policy. Journal of Rural and Community Development 4: 1, 102-117. <http://www.jrcd.ca/viewarticle.php?id=243>14.01.2015.

Wiberg U 2013. A competitive local and regional milieu for firms and people. In Lundström MJ, Fredriksson C \& Witzell J (eds). Planning for sustainable urban development in Sweden, 23-33. Swedish society for town and country planning, Stockholm.

Wilson S, Fesenmaier DR, Fesenmaier J \& Van Es JC 2001. Factors for success in rural tourism development. Journal of Travel Research 40: 2, 132-138. http://dx.doi.org/10.1177/004728750104000203.

Woods M 2005. Rural geography: processes, responses and experiences in rural restructuring. SAGE, London.

Woods M 2011. Rural. Routledge, London. 